\title{
Bacteriophages associated with multiresistant Staphylococcus aureus in Australia
}

\author{
D. M. WILKINSON, S. ANDREWS and P. R. STEWART
}

Department of Biochemistry, Faculty of Science, Australian National University, Canberra, ACT 2601, Australia

\begin{abstract}
Summary. Nineteen multiresistant strains of Staphylococcus aureus from Australian hospitals were examined for lysogenic bacteriophage. Thirteen strains contained prophage inducible with mitomycin $\mathrm{C}$. Three of these lysed completely on induction producing a phage referred to as type 1 ; this phage plated on $S$. aureus propagating strains 6, 53 and 77, which are hosts for phages of serogroup-lysogroup A III, B III and F III respectively. Type-1 phage did not plate on other propagating strains representative of the other serogroup-lysogroup combinations in the International Typing Set for $S$. aureus. Ten strains of $S$. aureus lysed incompletely when treated with mitomycin $C$, yielding phage type 2 , that plated only on propagating strain 6 . The virions of phage types 1 and 2 had isometric heads and flexible tails, and the genome consisted of $c .40$ kilobases of double stranded DNA. The DNA from the two phage types was different, as shown by endonuclease digestion and by hybridisation to reference phage DNAs. The remaining six $S$. aureus strains contained no phage inducible with either mitomycin $\mathrm{C}$ or ultraviolet irradiation. However, all contained type 2 DNA, as shown by Southern blotting, present presumably in a defective prophage state. Moreover, the three strains yielding type-1 phage on induction also contained type-2 DNA. Thus, type-2 DNA was found in all 19 strains of multiresistant $S$. aureus from geographically diverse Australian hospitals.
\end{abstract}

\section{Introduction}

During the 1970s, strains of methicillin-resistant Staphylococcus aureus spread epidemically throughout major Australian metropolitan hospitals and have since persisted in most of these centres. They are a clinically significant group because, apart from their generalised resistance to the $\beta$-lactam antibiotics, they are also resistant to a wide range of other antibiotics usually effective against $S$. aureus.

Two studies have reported on the microbiological and genetic characteristics of Australian isolates of multiresistant $S$. aureus (MRSA). Gedney and Lacey (1982) examined biochemical features of 78 strains of MRSA obtained from Australian hospitals in 1981 and concluded that, in general, they were similar to strains from other countries, possessing no novel features that might account for their epidemic spread or persistence throughout Australia. Lyon et al. (1984) examined the molecular properties of the plasmids carried by a range of MRSA isolates from major Australian cities and

Received 30 Apr. 1986; accepted 30 Jul. 1986. concluded that the similarities of the plasmids were such as to suggest the dissemination of a multiresistant strain of $S$. aureus, or some derivative, to hospitals throughout Australia. Interestingly, the range of phage-typing patterns of the 19 strains they examined was more diverse than the range of plasmids carried, although sensitivity to phages 80 or 85 occurred in the majority of the strains.

The capacity of aureophages to cause lysogenic conversion of several enzymes thought to be associated with staphylococcal virulence has been demonstrated (de Waart et al., 1962; Rosendal et al., 1964; Jollick, 1972; Kondo et al., 1973; Mason and Allen, 1975; Kondo and Fujise, 1977; DuvalIflah et al., 1977; Betley and Mekalanos, 1985; Lee and Iandolo, 1985). It is also well established that these phages act as vectors for antibiotic-resistance genes and mediate the conjugative transfer of plasmid and chromosomal genes (Lacey, 1980; Schaefler, 1982).

It seems likely, therefore, that aureophages could account for an important part of the pathogenic potential of staphylococcal populations or of individual strains. Accordingly, we have sought to identify whether particular phages are associated with particular populations of $S$. aureus. 


\section{Materials and methods}

\section{Bacteria and bacteriophages}

Nineteen isolates of MRSA from Australian hospitals were provided by Dr R. Skurray, Monash University, Melbourne. These corresponded to the strains examined in detail for plasmids by Lyon et al. (1984). The 18 strains resistant to methicillin were maintained on Trypticase Soy Agar (TSA; BBL Microbiology Systems, Cockeysville, MD, USA) plates containing methicillin $12.5 \mu \mathrm{g} / \mathrm{ml}$. Strain SK 676, which is sensitive to methicillin, was kept on antibiotic-free plates.

Aureophages and propagating strains of the International Typing Set were obtained from the American Type Culture Collection (Rockville, MD, USA). S. aureus strain ISP 8 (8325-4 pig 131) was obtained from Dr P. Pattee, Iowa State University, and strain C5 from Dr E. D. Rosenblum, University of Texas, USA.

\section{Induction of phages from clinical strains}

Phages were induced from early log phase $\left(\mathrm{A}_{580} c\right.$. $0 \cdot 1)$ cultures grown at $37^{\circ} \mathrm{C}$ in Trypticase Soy Broth (TSB; BBL) by adding mitomycin C $2 \mu \mathrm{g} / \mathrm{ml}$. Phage was titrated by spotting $10 \mu \mathrm{l}$ of serially-diluted filtered lysate on to agar overlays containing different propagating strains. Phages induced in 3-ml cultures were examined by electronmicroscopy and used in the determination of host range. Phage from $300-\mathrm{ml}$ cultures were purified on $\mathrm{CsC} 1$ gradients and the DNA extracted (Stewart et al., 1985). If these cultures had not lysed within $3 \mathrm{~h}$ after mitomycin $\mathrm{C}$ addition, lysis was accelerated by adding lysostaphin (Sigma) $5 \mu \mathrm{g} / \mathrm{ml}$ to the cultures. Strains that did not yield phage when treated with mitomycin $\mathrm{C}$ were tested for induction with UV irradiation at $254 \mathrm{~nm}$ applied to kill $99 \%$ of the cells.

\section{Propagation of phage by infection}

Phages induced from 3-ml cultures were filtered $(0.22 \mu \mathrm{m}$ membrane; Millipore) before infection of 300 $\mathrm{ml}$ cultures of $S$. aureus propagating strains. Infections were performed at a multiplicity of infection of $c .0 \cdot 1$ as described previously (Stewart et al., 1985). If small-scale broth inductions gave phage titres too low to initiate infections in $300-\mathrm{ml}$ cultures, then confluent lysis of propagating strains in agar overlays was used to produce sufficient infecting phage. Overlay propagation of phage was also used to increase the titre when phage were plaque purified.

\section{Host range assay of induced phage}

Dilutions of lysates from mitomycin C-treated cultures were plated on to ten propagating strains from the International Typing Set. These strains were selected as representative of the lysogroup and serogroup combinations in the typing set. The strains used (and the groups they represent) were: Ps 3C (IIA); Ps 6 (IIIA); Ps 81 (Misc. A), Ps 52 and Ps 80 (IB), Ps 71 (IIB), Ps 53 (IIIB), Ps 77 (IIIF), Ps 42D (IVF), and Ps 187 (Misc. L).

\section{Electronmicroscopy}

Phage virions were concentrated by centrifuging $175 \mu \mathrm{l}$ of lysate in a Beckman Airfuge at $20 \mathrm{psi}(85000 \mathrm{~g})$ for $20 \mathrm{~min}$. The supernate was removed, leaving $c .10 \mu \mathrm{l}$ of liquid in which the pellet was gently resuspended with a pasteur pipette. Where this treatment appeared to disrupt virion structure, phage was concentrated by precipitation with polyethylene glycol (PEG): lysate $900 \mu 1,5 \mathrm{M} \mathrm{NaCl}$ $225 \mu \mathrm{l}$, and PEG $600040 \% \mathrm{w} / \mathrm{v} 375 \mu \mathrm{l}$ were mixed in a 1.5-ml Eppendorf centrifuge tube. After $60 \mathrm{~min}$ at $4^{\circ} \mathrm{C}$, the mixture was centrifuged for $7 \mathrm{~min}$ in an Eppendorf bench centrifuge. The supernate was then removed and the tube inverted to drain for $5 \mathrm{~min}$. The pellet was covered with $20-30 \mu$ of buffer $(0 \cdot 1 \mathrm{M} \mathrm{NaCl}, 0.05 \mathrm{M}$ Tris-

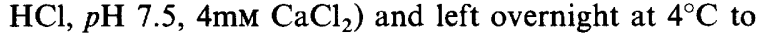
allow the virions to resuspend.

Copper grids (coated with formvar $0.3 \% \mathrm{w} / \mathrm{v}$ in ethylene dichloride) were placed on a drop of the phage suspension for $60 \mathrm{~s}$, lifted off, and the excess liquid removed with filter paper. The grid was then placed on a drop of filtered ammonium molybdate $3 \% \mathrm{w} / \mathrm{v}$ for $60 \mathrm{~s}$, blotted with filter paper and allowed to dry in air. In some cases, grids were first coated with poly-L-lysine to increase adherence of virions to grids. Phage dimensions were not significantly affected by poly-L-lysine.

Grids were examined with an Hitachi 500 transmission electronmicroscope at a magnification of 48 000-70 000 . The microscope was calibrated with catalase crystals with a periodicity of $8.75 \times 6.85 \mathrm{~nm}$ and with cross and line grating replicas. Twenty virions were measured in each sample, as recommended by Ackerman et al. (1978).

\section{Restriction endonuclease digestion of phage DNA}

DNA was digested for $90 \mathrm{~min}$ at $37^{\circ} \mathrm{C}$ with EcoRI or HindIII (Pharmacia, North Ryde, NSW) in high and medium salt buffers (Maniatis et al., 1982) respectively. Digested DNA was electrophoresed at room temperature for $3.4 \mathrm{~h}$ at $80 \mathrm{~V}$ in agarose $1.2 \% \mathrm{w} / \mathrm{v}$ gels containing ethidium bromide $0.5 \mu \mathrm{g} / \mathrm{ml}$. Gels were stained further with ethidium bromide $2 \mu \mathrm{g} / \mathrm{ml}$ and destained in distilled water before being photographed over an ultraviolet transilluminator. Lambda DNA cut with EcoRI or HindIII, and pBR322 cut with AluI (Boehringer Mannheim, North Ryde, NSW), were used as fragmentsize markers.

\section{DNA-DNA hybridisation}

Phage DNA was labelled with ${ }^{32} \mathrm{P}$-dCTP by nick translation (Stewart et al., 1985). DNA from selected phages of the International Typing Set was spotted (50 and $250 \mathrm{ng}$ ) on to Zeta Probe nylon membranes (BioRad, Richmond, CA, USA) by use of a Bio-Rad Bio-dot 
apparatus. Prehybridisation and hybridisation incubations were performed as described previously (Stewart et al., 1985). The filters were then washed with $0 \cdot 2 \times$ SSC (saline-sodium citrate; full strength medium is $0.15 \mathrm{M}$ $\mathrm{NaCl}, 0.015 \mathrm{M}$ sodium citrate, $p \mathrm{H} \mathrm{7.0)}$ at $55^{\circ} \mathrm{C}$; individual dots were cut from them, and bound radioactivity was measured in each sample by Cerenkov radiation.

\section{Detection of prophage in cellular DNA}

Cellular DNA (100-400 $\mu \mathrm{g}$ ) was prepared from $20-\mathrm{ml}$ stationary-phase broth cultures (shaken overnight at $37^{\circ} \mathrm{C}$ ). Cells were centrifuged at $12000 \mathrm{~g}$ for $10 \mathrm{~min}$ at $4^{\circ} \mathrm{C}$ and washed twice in $5 \mathrm{ml}$ of TES ( $30 \mathrm{~mm}$ Tris- $\mathrm{HCl}$, $50 \mathrm{mM} \mathrm{NaCl}, 5 \mathrm{~mm}$ EDTA, $p H$ 7.8). Cells were then lysed by resuspending in $2 \mathrm{ml}$ of TES containing $2.5 \mathrm{M} \mathrm{NaCl}$ and lysostaphin $30 \mu \mathrm{g} / \mathrm{ml}$ and gently shaking for $60 \mathrm{~min}$ at $37^{\circ} \mathrm{C}$. EDTA and Sarkosyl were added to the cell suspension to final concentrations of $0 \cdot 1 \mathrm{M}$ and $2 \% \mathrm{w} / \mathrm{v}$ respectively, the suspension was mixed by inversion and incubated at $65^{\circ} \mathrm{C}$ for $20 \mathrm{~min}$. TE $(10 \mathrm{~mm}$ Tris- $\mathrm{HCl}, 1 \mathrm{mM}$ EDTA, $p \mathrm{H} \mathrm{7.5)} 1 \mathrm{ml}$ and phenol $3.8 \mathrm{ml}$ were added and the lysate extracted twice with phenol. After precipitation with ethanol $70 \% \mathrm{v} / \mathrm{v}$, the DNA was dissolved in $750 \mu \mathrm{l}$ of TE and treated with RNAase $50 \mu \mathrm{g} / \mathrm{ml}$ overnight at $4^{\circ} \mathrm{C}$. A further $50 \mu \mathrm{g} / \mathrm{ml}$ of RNAase was then added to the dissolved DNA and incubated at $37^{\circ} \mathrm{C}$ for $60 \mathrm{~min}$. The DNA solution was then layered on to salt cushions $(3.65 \mathrm{ml}$ containing $1 \mathrm{M} \mathrm{NaCl}, 50 \mathrm{~mm}$ Tris- $\mathrm{HCl}, 5 \mathrm{~mm}$ EDTA, $p \mathrm{H} \mathrm{8.0)}$ and centrifuged for $3 \mathrm{~h}$ at $350000 \mathrm{~g}$ at $20^{\circ} \mathrm{C}$. The pelleted DNA was then resuspended in TE.

DNA was digested with HindIII, electrophoresed in agarose $1.2 \% \mathrm{w} / \mathrm{v}$ gels, then transferred to Zeta Probe nylon membranes (Reed and Mann, 1985). The transferred DNA was prehybridised for 18-24 $\mathrm{h}$ with gentle shaking at $42^{\circ} \mathrm{C}$ in $5 \times \mathrm{SSC}$ containing deionised formamide $50 \% \mathrm{v} / \mathrm{v}$, skimmed milk powder $0.5 \% \mathrm{w} / \mathrm{v}$, SDS $1 \% \mathrm{w} / \mathrm{v}, 25 \mathrm{~mm}$ sodium phosphate, $p \mathrm{H} 6 \cdot 5$, and sheared, heat-denatured salmon sperm DNA $250 \mu \mathrm{g} / \mathrm{ml} .{ }^{32} \mathrm{P}$ labelled phage DNA (denatured in $0.2 \mathrm{M} \mathrm{NaOH}$ at $100^{\circ} \mathrm{C}$ for $5 \mathrm{~min}$ ) was used to probe the filter-bound DNA under the same conditions used for prehybridisation. Membranes were then washed four times for $10 \mathrm{~min}$ with $0.2 \times \mathrm{SSC}$, SDS $0.1 \% \mathrm{w} / \mathrm{v}$ at $55^{\circ} \mathrm{C}$ and exposed to X-ray film. Membranes were reprobed with different ${ }^{32} \mathrm{P}$ labelled phage DNA after stripping the previous probe from filters by washing membranes 4 times for $10 \mathrm{~min}$ in $0 \cdot 1 \times \operatorname{SSC}$, SDS $0 \cdot 1 \% \mathrm{w} / \mathrm{v}$ at $95^{\circ} \mathrm{C}$. Stripped membranes were exposed to $\mathrm{X}$-ray film to check for residual probe before reprobing.

\section{Results}

\section{Detection of inducible prophage in clinical isolates}

Thirteen of the $19 S$. aureus clinical isolates from Australian hospitals contained inducible phage (table I). The remaining six strains did not yield phage when treated with mitomycin C or with UV irradiation. The presence of inducible phage in the strain tested was judged on one or more of the following criteria: lysis (complete or partial as judged by a reduction in optical density) of induced cultures; plaque formation when induced culture supernates were plated on ten different phagepropagating strains representative of the different lytic and serological groups in the International Typing Set; and the presence of phage virions when pellets from cell-free lysates were negatively-stained and examined by electronmicroscopy.

\section{Lytic spectrum and lysis of induced cultures}

The $13 S$. aureus clinical isolates containing inducible prophage could be divided into two groups on the basis of the lytic spectrum of the induced phages (table I). The first group produced phage lysing the lytic-group-III propagating strains Ps 6, Ps 53 and Ps 77; the second group yielded phage that lysed only Ps 6. Cultures of the first group lysed almost totally after induction with mitomycin $\mathrm{C}$, whereas the second group lysed incompletely at best.

Phage lysates induced from the first group gave lower titres on Ps 53 and Ps $77\left(10^{5}-10^{6} \mathrm{pfu} / \mathrm{ml}\right)$ than on Ps $6\left(10^{8}-10^{9} \mathrm{pfu} / \mathrm{ml}\right)$. Furthermore, plaque-purified phage from this group, when propagated on Ps 6 or Ps 53, yielded lysates that plated on Ps 6 but not on Ps 53 or Ps 77; lysates generated on Ps 77, by contrast, plated equally well on Ps 6, Ps 53 and Ps 77. Representative phage clones from the second group, plaque purified on Ps 6, plated back on Ps 6 without difficulty.

\section{Electronmicroscopy of induced and infected lysates}

Virions were detected by electronmicroscopy only in the case of those strains of $S$. aureus that yielded titratable phage (table I).

All of the aureophages detected were of the B1 morphotype (Ackermann et al., 1984) with an isometric head and elongate flexible tail. Head diameters and tail lengths were relatively uniform in aureophages induced from the first group of staphylococci, but differed for virions from the second group (table II).

\section{Endonuclease digestion of aureophage DNA}

Endonuclease digestion of phage DNA with EcoRI and HindIII enzymes revealed only two DNA types, designated type 1 and type 2 (fig. 1). These DNA types corresponded to the phage groups based on the lytic patterns: type-1 DNA was found in phages lysing Ps 6, 53 and 77, and 
Table I. Characteristics of aureophages derived from induced cultures of multiresistant $S$. aureus clinical isolates

\begin{tabular}{|c|c|c|c|c|c|c|}
\hline \multicolumn{3}{|c|}{ S. aureus isolates } & \multicolumn{4}{|c|}{ Induced phages } \\
\hline $\begin{array}{l}\text { Isolate } \\
\text { SK no. }\end{array}$ & Source* & $\begin{array}{l}\text { Phage } \\
\text { type† }\end{array}$ & $\begin{array}{c}\text { Lytic } \\
\text { spectrum on } \\
\text { propagating } \\
\text { strain(s) }\end{array}$ & $\begin{array}{l}\text { Lysis } \\
\text { of } \\
\text { induced } \\
\text { culture }\end{array}$ & $\begin{array}{l}\text { Detection of } \\
\text { virions by } \\
\text { electron- } \\
\text { microscopy }\end{array}$ & $\begin{array}{l}\text { DNA } \\
\text { type }\end{array}$ \\
\hline 634 & A & $80 / 85$ & $6 / 53 / 77$ & + & + & 1 \\
\hline 637 & A & $29 / 79 / 80$ & $6 / 53 / 77$ & + & + & 1 \\
\hline 656 & H & NT & $6 / 53 / 77$ & + & + & 1 \\
\hline 436 & $\mathrm{~S}$ & $80 / 85$ & 6 & - & + & 2 \\
\hline 529 & $\mathbf{M}$ & $80 / 85$ & 6 & - & + & 2 \\
\hline 568 & B & 80 & 6 & - & + & 2 \\
\hline 597 & $\mathrm{~S}$ & NT & 6 & - & + & 2 \\
\hline 604 & $\mathbf{M}$ & $77 / 80 / 84 / 85$ & 6 & - & + & 2 \\
\hline 676 & A & $29 / 79 / 80$ & 6 & - & + & 2 \\
\hline 963 & $\mathrm{P}$ & $84 / 85$ & 6 & - & + & 2 \\
\hline 460 & $\mathbf{M}$ & $83 \mathrm{~A}$ & 6 & - & + & $2 \S$ \\
\hline 578 & D & $77 / 80$ & 6 & - & + & $2 \S$ \\
\hline 592 & $\mathrm{~S}$ & NT & 6 & - & + & $2 \S$ \\
\hline 456 & $\mathbf{M}$ & $29 / 53 / 83 \mathrm{~A} / 79 / 85$ & ND & - & - & ND \\
\hline 565 & B & 80 & ND & - & - & ND \\
\hline 569 & B & 80 & ND & - & - & ND \\
\hline 572 & $\bar{B}$ & 80 & ND & - & - & ND \\
\hline 588 & $\mathbf{S}$ & 80 & ND & - & - & ND \\
\hline 625 & $\mathrm{~S}$ & $80 / 85$ & ND & - & - & ND \\
\hline
\end{tabular}

$\mathrm{ND}=$ not detected due to phage being uninducible.

* A Adelaide, H Hobart, S Sydney, M Melbourne, B Brisbane, P Perth, D Darwin.

$\dagger$ From Lyon et al. (1984); NT= not typable.

$¥$ Defined in text and fig. 1 .

$\S$ Induction did not yield sufficient DNA for analysis. However, ${ }^{32} \mathrm{P}$-labelled type-2 phage

DNA hybridised to phage DNA present in endonuclease-digested total cell DNA.

Table II. Dimensions of phage virions induced from MRSA strains

\begin{tabular}{ccc} 
& \multicolumn{2}{c}{ Induced phages } \\
\cline { 2 - 3 } $\begin{array}{c}\text { S. aureus } \\
\text { isolate SK no. }\end{array}$ & $\begin{array}{c}\text { Head, mean diameter } \\
(\mathrm{nm}) \pm \mathrm{SD}\end{array}$ & $\begin{array}{c}\text { Tail, mean length } \\
(\mathrm{nm}) \pm \mathrm{SD}\end{array}$ \\
\hline & & \\
634 & $46.4 \pm 2.4$ & $149 \cdot 9 \pm 10 \cdot 8$ \\
637 & $47 \cdot 8 \pm 1 \cdot 4$ & $152 \cdot 9 \pm 5 \cdot 5$ \\
656 & $48 \cdot 5 \pm 2 \cdot 6$ & $162 \cdot 0 \pm 5 \cdot 5$ \\
436 & $45 \cdot 4 \pm 2 \cdot 7$ & $175 \cdot 1 \pm 9 \cdot 8$ \\
529 & $41 \cdot 2 \pm 1 \cdot 7$ & $162 \cdot 2 \pm 4 \cdot 5$ \\
568 & $44 \cdot 8 \pm 1 \cdot 8$ & $195 \cdot 4 \pm 9 \cdot 7$ \\
597 & $49 \cdot 2 \pm 3 \cdot 1$ & $210 \cdot 3 \pm 7 \cdot 2$ \\
604 & $40 \cdot 9 \pm 1 \cdot 4$ & $143 \cdot 8 \pm 5 \cdot 5$ \\
676 & $42 \cdot 9 \pm 3 \cdot 4$ & $157 \cdot 3 \pm 8 \cdot 1$ \\
963 & $49 \cdot 5 \pm 3 \cdot 2$ & $190 \cdot 2 \pm 4 \cdot 1$ \\
460 & $44 \cdot 3 \pm 1 \cdot 4$ & $193 \cdot 9 \pm 12 \cdot 7$ \\
578 & $49 \cdot 6 \pm 2 \cdot 2$ & $180 \cdot 1 \pm 13 \cdot 7$ \\
592 & $44 \cdot 9 \pm 1 \cdot 8$ & $188 \cdot 0 \pm 9 \cdot 9$ \\
& & \\
\hline
\end{tabular}

type-2 DNA was found in phage lysing Ps 6 only (table I). Endonuclease digests of type-1 phage DNA contained faint bands corresponding to type2 DNA fragments, indicating the presence of trace amounts of type- 2 phage in the type-1 preparations. These type-2 DNA fragments were not present, however, when a type-1 phage (from strain SK 637) was plaque purified on Ps 6 and ISP 8, a non lysogen.

Summation of fragment sizes indicated that the total genome size for the two aureophage types was approximately $40 \mathrm{~kb}$. Phage-11 DNA was used as a reference genome in these experiments; the sizes of fragments generated from this DNA by digestion with EcoRI agreed with the results reported previously (Bächi 1980; Löfdahl et al., 1981). When type-1 phage was propagated on Ps 6 (with or without plaque purification) the endonucleasegenerated fragments from this phage DNA were the same as those seen for DNA from induced lysogens. However, propagation of type-1 phage 


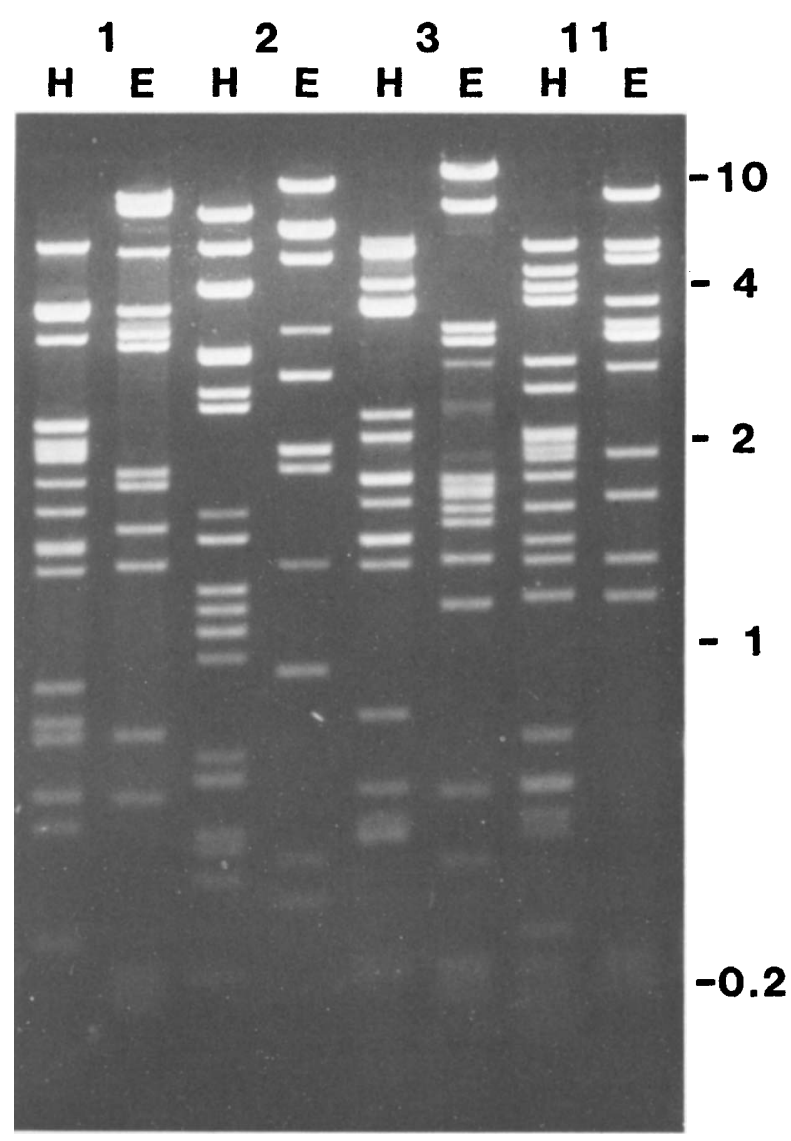

Fig. 1. Electrophoresis of endonuclease digests of phage DNA. Endonucleases used are indicated as $\mathrm{H}($ HindIII) and $\mathrm{E}(E c o \mathrm{RI})$, and DNA types 1,2 and 3 are described in the text. Reference DNA is from phage 11 and numbers at the side of the gel refer to sizes in $\mathrm{kb}$.

(plaque purified from S. aureus strain SK 637) on Ps 77 and designated 637/77, resulted in an altered endonuclease-fragment pattern for the DNA. This DNA is referred to as type 3 (fig. 1). Endonuclease digests of type-3 DNA contained some fragments of similar mol. wt to type-1 DNA, but fragments different from those in type-1 DNA accounted for approximately half of the length of the genome. This may represent a recombinant phage, and is being examined more closely. The estimated size of type-3 phage DNA was $37 \mathrm{~kb}$.

\section{DNA homologies of induced phages}

Filter hybridisation of types 1,2 and 3 DNAs showed that types 1 and 3 were related to the extent of $c .80 \%$ homology, and related equally to reference phage DNAs representing different serogroups and lysogroups (table III). Greatest homology of these two DNAs was found with serogroup-B phage
Table III. Homology of representative phage DNA*

\begin{tabular}{|c|c|c|c|}
\hline \multirow{2}{*}{$\begin{array}{l}\text { Unlabelled } \\
\text { phage DNA* }\end{array}$} & \multicolumn{3}{|c|}{$\begin{array}{l}\text { Percentage homology by DNA-DNA hybridi- } \\
\text { sation with }{ }^{32} \mathrm{P} \text {-labelled phage DNA }\end{array}$} \\
\hline & Type 1 & Type 3 & Type 2 \\
\hline Type 1 & 100 & 76 & 8 \\
\hline Type 3 & 83 & 100 & 4 \\
\hline Type 2 & 11 & 6 & 100 \\
\hline Type $1 \dagger$ & 102 & 74 & 9 \\
\hline $3 C$ & 1 & 3 & 2 \\
\hline 75 & 3 & 5 & 2 \\
\hline $52 \mathrm{~A}$ & 16 & 20 & 2 \\
\hline 71 & 17 & 34 & 2 \\
\hline $83 \mathrm{~A}$ & 53 & 56 & 23 \\
\hline 11 & 48 & 51 & 1 \\
\hline 84 & 12 & 15 & 35 \\
\hline 187 & 11 & 12 & 5 \\
\hline
\end{tabular}

* Type-1 phage DNA was from strain SK 637 except for $\dagger$, where it was induced from strain SK 634; type-2 phage DNA was from SK 604; type-3 phage DNA is explained in text. Phages $3 \mathrm{C}$ and 75 are from serogroup $\mathrm{A}$; phages $52 \mathrm{~A}, 71,83 \mathrm{~A}$ and 11 from serogroup $B$; and phages 84 and 187 are from serogroups $\mathbf{F}$ and miscellaneous respectively.

DNA, especially with the lytic-group III phages $83 \mathrm{~A}$ and 11 . Type-1 DNA from phage induced from different hosts (SK 634 and 637) gave comparable homologies when hybridised with different reference DNAs, confirming the endonuclease digestion results.

Type-2 DNA was most closely related to the lytic-group III phages $83 \mathrm{~A}$ (serogroup B) and 84 (serogroup F), though the homology was not high (23\% and $35 \%$ respectively). Homology of type- 2 DNA to types 1 and 3 was low (c. $10 \%$ and $5 \%$ respectively).

\section{Presence of prophage in MRSA strains}

The possibility that those strains that did not yield free phage on induction might nevertheless contain defective (non-inducible) prophage was examined by isolating total cell DNA from the strains, and probing endonuclease digests of this DNA with labelled type-1 or -2 phage DNA.

Cellular DNA from all 19 multiresistant strains contained phage-type-2 DNA (fig. 2) whereas only three strains contained phage-type-1 DNA: SK 634, SK 637 (not shown) and SK 656, i.e., these three strains contained both phages. When host strain SK 568 (which contained only type-2 phage) was lysogenised with phage 637 (type 1, from strain SK 637), induction of the lysogen yielded predomi- 


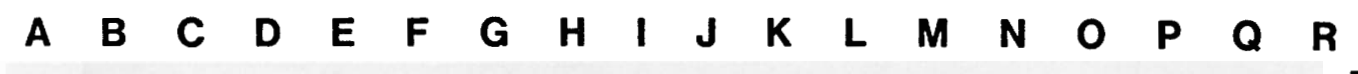
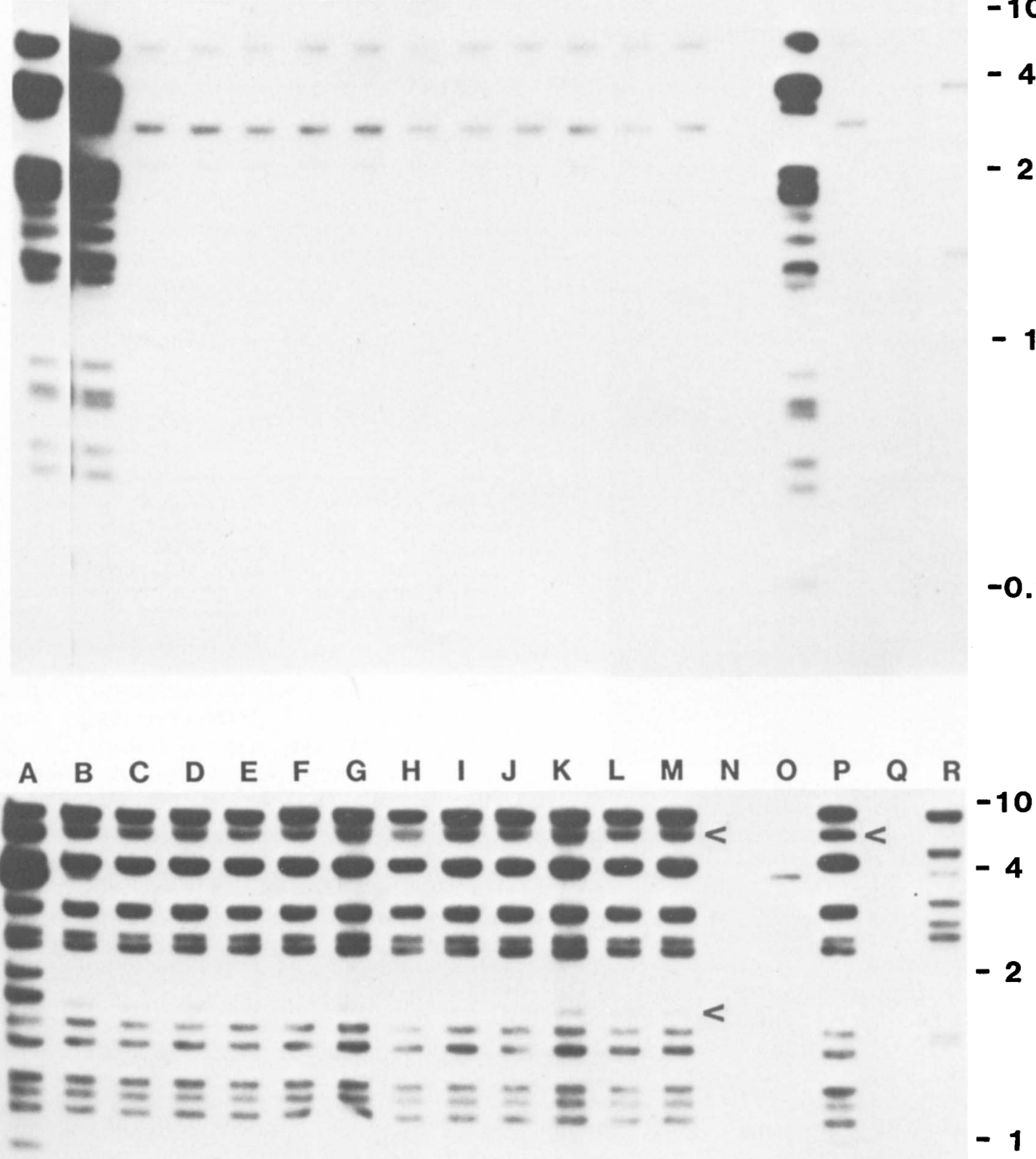
nantly phage-type 1 . This was shown by probing plaque lifts (generated on Ps 6) with labelled type1 and type-2 DNA. Approximately $1 \%$ of plaques contained type-2 DNA; this is consistent with the submolar amounts of type-2 DNA found in phage induced from strains SK 634, 637 and 656. This phenomenon of one phage replicating preferentially is under further investigation.

Type-2 prophage in all 19 strains was recognisable by the presence of two HindIII fragments (c. $1 \cdot 7$ and $c 5.8 \mathrm{~kb}$ ) not present in virion DNA but partially homologous to virion DNA (fig. 2(b); lanes A-M). These fragments are probably the prophage-chromosome junction fragments. The low intensity of the $1 \cdot 7-\mathrm{kb}$ fragment probably reflects that it is predominately chromosomal. Calculation indicates that $c .2 \cdot 2 \mathrm{~kb}$ of chromosome DNA is fully conserved in this prophage insertion region across all 19 strains. Conversely, type-2 virion DNA was recognisable by a $5 \cdot 3-\mathrm{kb}$ HindIII fragment not present in prophage DNA (fig. 2(b); lane $\mathrm{P})$. This fragment is thought to contain the attachment sequence in the phage genome that recognises and recombines with the integration site in the host-cell chromosome.

C5, an MRSA strain from the USA, did not contain type- 1 or type- 2 prophage, but contained prophage DNA that was partly homologous to types 1 and 2 phage DNA (lane R).

\section{Discussion}

Two types of prophage were inducible in 13 of the 19 strains of MRSA tested in this study. These phages were referred to as types 1 and 2 on the basis of differences in lytic spectra and endonucleasegenerated fragments from their DNA. The remaining six strains contained a non-inducible (defective state) prophage that was the same as, or closely related to, type- 2 phage as demonstrated by homology of phage 604 (type 2, from strain SK604) with all but two corresponding endonucleasegenerated fragments (tentatively designated as the prophage-chromosome junction fragments) in cell DNA from these strains.

Interestingly, while virion dimensions were uni- form for the three type-1 phages, they were not so for the ten type-2 phages, even though the DNA endonuclease fragments and lytic spectra for type2 phages were the same. This suggests that the type2 phages are genetically diverse at a finer level of resolution, or that host-cell functions (differing according to the wild host strain induced) are involved in determining virion dimensions.

Thus, while the strains of $S$. aureus examined in this study were of geographically diverse origins, and had a range of phage-typing patterns, they appeared to carry a quite narrow population of prophage. A similar conclusion has been drawn in respect of the plasmids carried by these strains (Lyon et al., 1984). This suggests either that selective processes have operated on the Australian strains, both for plasmid types (presumably, in part at least, as a consequence of the range of antibiotics to which these strains have been exposed) and for prophages (defective or inducible), or that they represent members of a single clone that has radiated into the hospitals sampled.

The nature of the environmental determinants acting to select and to maintain the narrow range of phage associated with these Australian isolates can only be speculated for the moment. There are two possibilities which we are currently testing. Firstly, the prophage genomes may carry genes that directly determine aspects of virulence of these MRSA strains, as has been demonstrated recently for a prophage carrying the enterotoxin A gene in a range of wild strains of $S$. aureus producing enterotoxin A (Betley and Mekalanos, 1985). The determination of pathogenicity in particular strains of Corynebacterium diphtheriae by phage- $\beta$ is the classical model for this type of host-phage interaction (Groman, 1984). Alternatively, insertion of prophage may occur at a specific site in the $S$. aureus chromosome, a consequence of which is the modulation or switching of particular chromosomal gene(s) concerned with virulence of the host, as has recently been demonstrated for lipase activity in $S$. aureus (Lee and Iandolo, 1985). It is notable, in this regard, that the insertion site of type- 2 phage appears to be constant as shown by the uniform sizes of the two junction fragments. Nevertheless,

\footnotetext{
Fig. 2. Autoradiograms of HindIII-digested cell DNA and phage DNA probed with phage-type $1{ }^{32} \mathrm{P}-\mathrm{DNA}$ (a), and phage-type 2 ${ }^{32}$ P-DNA (b). Cell DNA and phage DNA were loaded at $c .1 \mu \mathrm{g}$ and $c .20 \mathrm{ng}$ respectively. Tracks A-M are cell DNA from representatives of the multiresistant $S$. aureus strains: (A) SK 634-the overnight culture had partially lysed so that a relatively large proportion of type-1 phage DNA was present; (B) SK 656; (C) SK 436; (D) SK 529; (E) SK 568; (F) SK 597; (G) SK 676; (H) SK 963; (I) SK 565; (J) SK 569; (K) SK 572; (L) SK 588; (M) SK 625. Track (N) is DNA from ISP 8, a non-lysogen. Tracks (O) and (P) are phage DNA types 1 and 2 induced from strains SK 656 and SK 604 respectively. Track Q contains phage lambda and plasmid fragments as standards. Track $R$ is cell DNA from C5, an MRSA from USA. Numbers at the side of the gel are sizes of DNA fragments in $\mathrm{kb}$. Fragments indicated with arrows in (b) are thought to be the prophage-chromosome junction fragments (tracks A-M) and in track P the fragment of the phage genome containing the attachment site (see text).
} 
random insertion of phage into the host chromosome, as occurs in the case of coliphage mu, could also be accommodated into models of lysogenic conversion of virulence determinants in $S$. aureus.

Beard-Pegler and Vickery (1985) have recently reported the presence of a common lysogenising phage (designated C) in 21 of 23 strains of MRSA isolated over a period of 5 years in a large Sydney hospital. Four strains contained another lysogenising phage in addition to phage $C$, and two strains were not detectably lysogenic. The phages lysogenising these MRSA were characterised serologically and by host range, and so cannot be compared directly with those identified in the present study. Nevertheless, the prevalence of phage $C$ seen by

\section{REFERENCES}

Ackermann H W, Audurier A, Berthiaume L, Jones L A, Mayo J A, Vidaver A K 1978 Guidelines for bacteriophage characterization. Advances in Virus Research 23: 1-24.

Ackermann H W, Cantor E D, Jarvis A W, Lembke J, Mayo J A 1984 New species definitions in phages of gram-positive cocci. Intervirology 22: 181-190.

Bächi B 1980 Physical mapping of the $B g I, B g l I, P s t I$ and EcoRI restriction fragments of staphylococcal phage $\phi 11$ DNA. Molecular and General Genetics 180: 391-398.

Beard-Pegler M A, Vickery A M 1985 Lysogenicity of methicillin-resistant strains of Staphylococcus aureus. Journal of Medical Microbiology 20: 147-155.

Betley M J, Mekalanos J J 1985 Staphyloccal enterotoxin A is encoded by phage. Science 229: 185-187.

de Waart J, Winkler K C, Grootsen C 1962 Lysogenic conversion in staphylococci. Nature 195: 407-408.

Duval-Iflah Y, Van Heijenoort J, Rousseau M, Raibaud P 1977 Lysogenic conversion for multiple characters in a strain of Staphylococcus aureus. Journal of Bacteriology 130: 12811291.

Gedney J, Lacey R W 1982 Properties of methicillin-resistant staphylococci now endemic in Australia. Medical Journal of Australia 1 : 448-450.

Groman N B 1984 Conversion by corynephages and its role in the natural history of diphtheria. Journal of Hygiene 93 : 405417.

Jollick J D 1972 Evidence for bacteriophage conversion in Staphylococcus. Microbios 6: 97-100.

Kondo I, Kurosaka K, Ishikawa T, Nakahara H, Fujise K 1973 Lysogenic conversion of $\beta$-hemolysin and staphylokinase by staphylococcal phage of serotype F. Genetics 74 Suppl: S143-S144.

Kondo I, Fujise K 1977 Serotype B staphylococcal bacteriophage
Beard-Pegler and Vickery (1985) is reminiscent of the general presence which we observed for type- 2 prophage (inducible or defective). Moreover, type$C$ phage belongs to serogroup $F$, by the criteria of Beard-Pegler and Vickery (1985), and we found that type-2 phage was also most closely related by DNA homology to the serogroup $F$ phage 84 . Furthermore, phage $C$ and our type- 2 phage plate on Ps 6 but not on Ps 53 and Ps 77. It is possible that phage-C and type- 2 phages are the same or similar, and we look forward to testing phage $\mathrm{C}$ for sequence homology with type- 2 phage.

We thank the National Health and Medical Research Council of Australia for financial assistance.

singly converting staphylokinase. Infection and Immunity 18: $266-272$.

Lacey R W 1980 Evidence for two mechanisms of plasmid transfer in mixed cultures of Staphylococcus aureus. Journal of General Microbiology 119 : 423-435.

Lee C Y, Iandolo J J 1985 Mechanism of bacteriophage conversion of lipase activity in Staphylococcus aureus. Journal of Bacteriology 164: 288-293.

Löfdahl S, Zabielski J, Philipson L 1981 Structure and restriction enzyme maps of the circularly permuted DNA of staphylococcal bacteriophage $\phi 11$. Journal of Virology 37: 784-794.

Lyon B R, Iuorio J L, May J W, Skurray R A 1984 Molecular epidemiology of multiresistant Staphylococcus aureus in Australian hospitals. Journal of Medical Microbiology 17: 79-89.

Maniatis T, Fritsch E F, Sambrook J 1982 Molecular cloning, a laboratory manual. Cold Spring Harbor Laboratory, Cold Spring Harbour, New York.

Mason R E, Allen W E 1975 Characteristics of Staphylococcus aureus associated with lysogenic conversion to loss of betahemolysin production. Canadian Journal of Microbiology 21: 1113-1116.

Reed K C, Mann D A 1985 Rapid transfer of DNA from agarose gels to nylon membranes. Nucleic Acids Research 13: 7207-7221.

Rosendal K, Bülow P, Jessen O 1964 Lysogenic conversion in Staphylococcus aureus, to a change in the production of extracellular 'Tween'-splitting enzyme. Nature 204: 12221223.

Schaefler S 1982 Bacteriophage-mediated acquisition of antibiotic resistance by Staphylococcus aureus type 88. Antimicrobial Agents and Chemotherapy 21 : 460-467.

Stewart P R, Waldron H G, Lee J S, Matthews P R 1985 Molecular relationships among serogroup $B$ bacteriophages of Staphylococcus aureus. Journal of Virology 55: 111-116. 